DIW BERLIN

Discussion

Papers
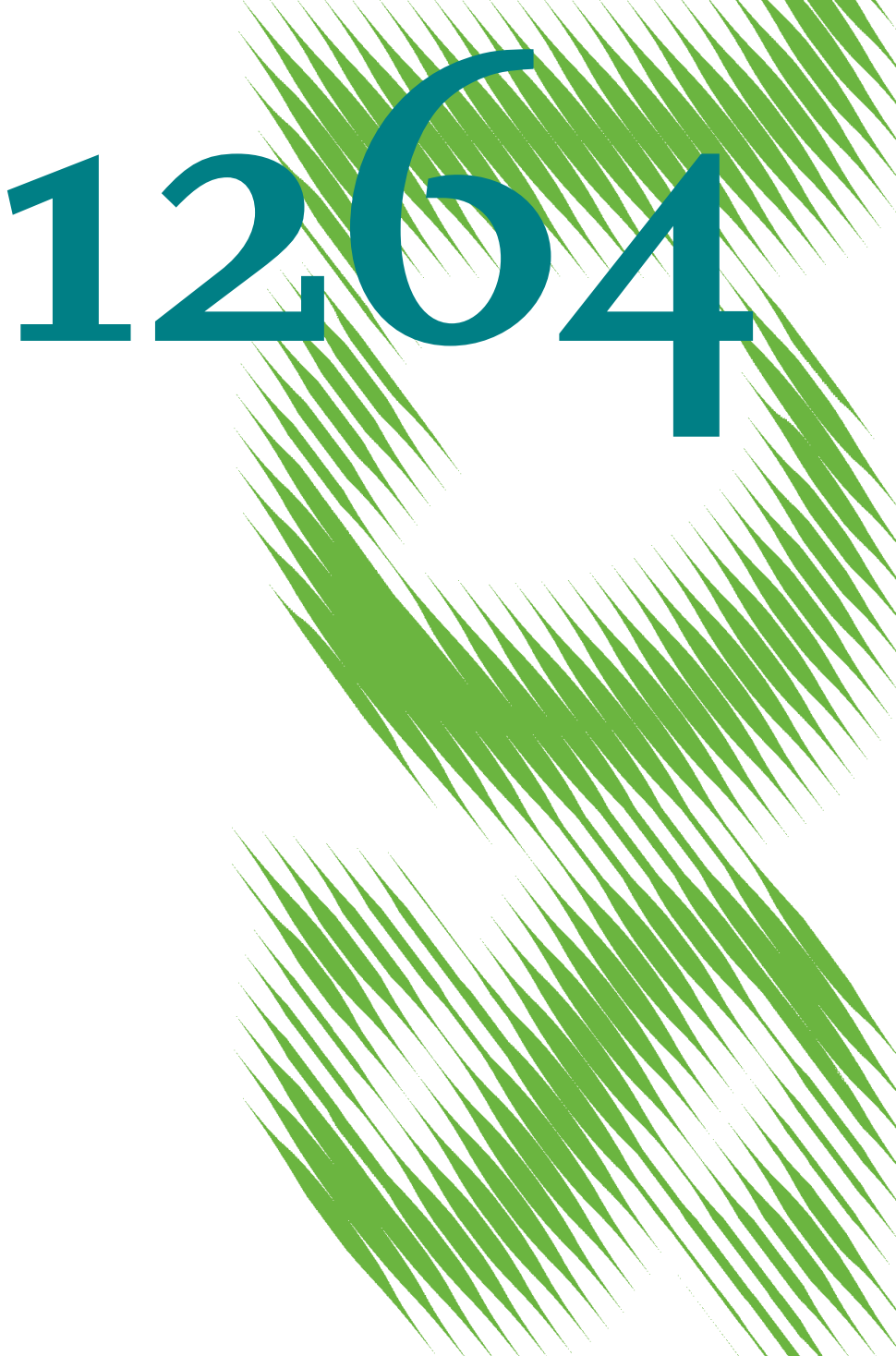

On the Relevance of Exports for Regional Output Growth in China 
Opinions expressed in this paper are those of the author(s) and do not necessarily reflect views of the institute.

IMPRESSUM

(C) DIW Berlin, 2013

DIW Berlin

German Institute for Economic Research

Mohrenstr. 58

10117 Berlin

Tel. $+49(30) 89789-0$

Fax +49 (30) $89789-200$

http://www.diw.de

ISSN print edition $1433-0210$

ISSN electronic edition 1619-4535

Papers can be downloaded free of charge from the DIW Berlin website:

http://www.diw.de/discussionpapers

Discussion Papers of DIW Berlin are indexed in RePEc and SSRN:

http://ideas.repec.org/s/diw/diwwpp.html

http://www.ssrn.com/link/DIW-Berlin-German-Inst-Econ-Res.html 


\section{On the relevance of exports for regional output growth in China}

\section{Christian Dreger and Yanqun Zhang ${ }^{1}$}

Abstract: Despite high economic growth during the last decades, China is still vulnerable to shocks arising from industrial states. The advanced economies determine Chinese export performance, with subsequent effects on output growth. Using a production function approach, this paper examines to which extent regional GDP growth in China is export driven. In a panel of 28 Chinese provinces, series are splitted into common and idiosyncratic components, the latter being stationary. The results indicate cointegration between the common components of GDP, the capital stock and exports. In equilibrium, exports increase GDP by more than their impact expected from the national accounts. While exports and capital are weakly exogenous, GDP responds to deviations from the long run. An adjustment pattern can be detected for almost all regions, except of some provinces in the Western part of the country.

JEL: F43, O11, C23

Keywords: Chinese economy, panel co-integration, expert led growth

\footnotetext{
${ }^{1}$ Dreger: German Institute for Economic Research (DIW Berlin), European University Viadrina Frankfurt Oder, Germany, email: cdreger@diw.de, Zhang: Chinese Academy of Social Sciences (CASS), Beijing, China, email: yqzhang@cass.org.cn.
} 


\section{$1 \quad$ Introduction}

The integration of China into the international economy is one of the most spectacular events in recent economic history. In only three decades, China transformed from an agricultural and closed economy to the second largest economy in the world, with a share exceeding 15 percent of GDP as measured in PPPs. In the aftermath of the financial crisis, China accounted for one third of global output growth, driven by huge fiscal packages. However, despite of its new role as a global manufacturing powerhouse, China cannot be considered as an autonomous pillar for international growth, at least not yet. Although growth has been high in the transition period, the country remains highly vulnerable to shocks from industrial countries, like the euro area debt crisis (Dreger and Zhang, 2011). Advanced countries determine the Chinese export performance, with subsequent effects on GDP growth. China can become a more independent growth engine with significant spillovers to other countries, if growth is driven by consumption to a higher degree.

-Figures 1 and 2 about here-

This paper explores to which extent Chinese GDP growth actually depends on its export activities. Exports have played a key role in past decades, and often expanded at higher rates than overall production (Figure 1). The exception is traced to the financial crisis, which led to temporary export losses in 2009 because of a sharp recession in industrial countries. Due to this shock, export growth has been below output growth even on average over some years. In line with strong export and investment growth, the consumption 
share in GDP decreased. Private household expenditures increased, but at a lower path (Figure 2).

According to the national accounts identity, a change in exports implies a change of equal amount in production. However, exports can contribute to GDP to an even higher degree, as a rise in productivity may be involved. This reaction is stressed by the export led growth hypothesis. Exports can finance imports that incorporate foreign technology, i.e. they promote knowledge spillovers, see Grossman and Helpman (1991). The more the country is engaged in foreign trade, the more it can invest in sectors with comparative advantage. Economies of scale can be exploited, as domestic demand is extended by the global market (Helpman and Krugman 1985). The tradable sector can generate positive externalities to non tradable, such as incentives for technological improvements, labor training and efficient management practices. Following Chen (2011), export variety, i.e. the participation of many sectors in export oriented activities can explain the correlation between provincial export revenue and productivity. But productivity gains cannot be seen as granted. Low-skilled workers can limit knowledge spillovers. A minimum level of technology and human capital in exporting firms may be necessary to acquire foreign technology.

This paper explores the relevance of the export-led growth hypothesis for the Chinese economy. Empirical evidence is based on 28 provinces. The incomplete economic integration across the country can affect the extent to which exports drive output growth in different provinces. Furthermore, the regional dimension extends the number of observations, implying better testing opportunities. The long run impact of exports on GDP is investigated within a cointegration analysis based on the common components of GDP, the capital stock and exports. The long run equilibrium can be established, where the 
long run elasticity of GDP with respect to exports exceeds the expected impact derived from the national accounts identity. Therefore, the export led growth hypothesis holds for the Chinese economy. Furthermore, GDP responds to deviations from the long run, while exports can be considered as weakly exogenous with respect to the cointegration relationship. Error correction models estimated at the provincial level indicate that the speed of adjustment is very similar across the different regions.

The rest of the paper is structured as follows. The next section (Section 2) reviews foreign trade reforms and export supporting strategies in China which have dominated the design of economic policies over the last decades. Then, the export led growth hypothesis is derived from a production function approach, and a testable equation is derived (Section 3). The econometric methodology is presented in Section 4, and the data and empirical results are discussed in Section 5. Finally, Section 6 concludes.

\section{$2 \quad$ Foreign trade reform and export supporting strategy of China}

Before opening to the outside world, China implemented a trade regime oriented toward import substitution. Plans in terms of trade quantities and composition were determined by the government, and carried out by a handful of state agencies. Before the reforms foreign trade accounted for 0.6 percent of world trade.

Starting in the early 1980 s, China began to reform the trade system in a gradual and incremental way. Reforms took place in four major areas: Trade liberalization, exchange rate marketization and devaluation, promotion of FDI and FIE (foreign invested enterprises), and accession to the WTO. Up to now, China has become the largest exporter of the world, with a share exceeding 10 percent. 
The decentralization of the trade system is characterized by the termination of trade plans and the enlargement of the number of foreign trade corporations. In the 1980s the central planning system was gradually dismantled. The state monopoly has been abandoned and market forces have played an increasing role since then. At the turn of the century, more than 90 percent of imports have been based on market forces (Branstetter and Lardy, 2006).

China has become an important destination for FDI and processing-trade business due to low labor cost, a relatively developed infrastructure, and a huge domestic market. With the opening process, China has taken measures to attract FDI and promote FIEs, especially in processing-trade sectors. Supporting measures include the lifting of controls over imports of intermediate inputs and capital goods, lower business income taxes for FIEs, and exemptions of tariffs on components imported for producing export products. Export-oriented and technologically advanced projects enjoyed additional preferential treatments (Bhat, 2012).

China's entry into the WTO in 2001 marks a cornerstone in the opening process. The WTO membership has strengthened China's competitive position and capacity of its firms in terms of technology and management, in addition to direct benefits from economic globalization (Branstetter and Lardy, 2006). In order to meet the WTO's requirements, laws and regulations have been rewritten to make them compliant with the prevailing regulations. In addition, reforms of the tariff system have been accelerated after the WTO entry.

The exchange rate regime has undergone reforms towards an increasing the role of market forces in its determination and promoting the convertibility of the Renminbi. Prior to the reform, the exchange rate was strictly controlled by the government. Foreign 
trade corporations were required to surrender foreign currency earnings from exports. A foreign currency retention scheme was introduced in 1979 and allowed export corporations to keep some proportion of their earnings. The swap market was established in 1989. Export oriented firms can trade retained foreign currency at a relatively free exchange rate. After a few years, more than 80 percent of the foreign exchange earnings have been priced at the swap rate, indicating that market forces played a dominant role in determining China's exchange rate. It should be noted that swap exchange rate has been lower than the official rate, indicating some fundamental overvaluation of the latter.

In 2005, China moved to a managed floating exchange rate regime based on market forces with reference to a basket of currencies. Although the Renminbi has been appreciated by more than 10 percent against the US Dollar since then, the Chinese export performance increased. This indicates some robustness of export activities against exchange rate changes.

\section{$3 \quad$ The export led growth hypothesis}

The export led growth hypothesis has been investigated by numerous papers with mixed results; see Dreger and Herzer (2012) for a recent survey. Often the findings are driven by empirical methods and the selection of countries. The evidence is quite limited with respect to China. Kwan and Kwok (1995) reported results supporting the leading role of exports for production, as they can be seen as exogenous. Shan and Sun (1998) investigated the direction of causality between exports and economic growth in a VAR system based on a production function. The results indicate bidirectional causality between ex- 
ports and industrial output in China. As the export-led growth hypothesis states a unidirectional causal ordering, it is rejected despite the positive contribution of exports to output. In a paper similar to the research presented here, Ljungwall (2006) looked at export-led growth at the provincial level by cointegration and causality tests. The hypothesis is validated for one half of the regions, most of them located in coastal areas. In the other provinces, the relationship is either bidirectional, or a one-way causal relationship from GDP to exports appears. However, the regional level might introduce a bias in the results, since provinces cannot be treated as independent. This problem is fixed in the current analysis, as cointegration is tested at the level of the common components of the series involved. By focusing on common elements, inter-regional supplier chains cannot drive the results. The export exposure of regional output is examined by panel error correction models. Since the cross section dimension is embedded, testing is done in a more efficient environment.

The point of departure to investigate the export led growth hypothesis is an $A K$ production function

(1) $Y_{i t}=A_{i t} K_{i t}^{\beta}$

where $Y$ is output, $A$ is the level of productivity, and $K$ the capital stock. Labour input is normalized to unity for convenience. The indices $i$ and $t$ denote region and time, respectively. It is assumed that the production elasticity of capital, $\beta$, does not strongly fluctuate across provinces. Exports $X$ have a direct affect on productivity

(2) $A_{i t}=f\left(X_{i t}\right)=X_{i t}^{\alpha}$ 
because of knowledge spillovers to the non-tradable sector. By substituting (2) into (1) and taking logs, the empirical specification

$$
\log Y_{i t}=\alpha \log X_{i t}+\beta \log K_{i t}+u_{i t}
$$

is obtained, where $u$ is a stationary error term. Any additional impact of exports on output beyond the effect that is already embedded via the national accounts requires that the export elasticity $\alpha$ exceeds the export share in GDP in the long run ${ }^{2}$. Furthermore, while output growth is expected to respond to deviations from the long run, exports should be as weakly exogenous.

\section{$4 \quad$ Econometric methods}

As the series are nonstationary, the export led growth hypothesis is explored in a cointegration framework. Standard unit root and cointegration tests are plagued by a low power problem against stationary alternatives see Campbell and Perron (1991). Therefore, a panel environment is preferred. Since the time series dimension is extended by the cross section, inference relies on a broader information set. However, cross section dependencies need to be taken into account. Chinese provinces cannot be seen as independent, as they are subject to common shocks.

Following Gengenbach, Palm and Urbain (2006) the starting point is a decomposition of each variable into common and idiosyncratic components, as suggested by Bai and $\mathrm{Ng}$ (2004). While the former are extracted via principal component analysis, the idiosyn-

\footnotetext{
${ }^{2}$ From the national accounts, GDP equal to the sum of consumption, investment, and exports minus imports, i.e. $Y=C+I+X-M$. This implies $\Delta Y / Y=(\Delta C / C)(C / Y)+(\Delta I / I)(I / Y)+(\Delta X / X)(X / Y)-(\Delta M / M)(M / Y)$. Hence, the income elasticity with respect to exports expected by the national accounts identity is equal to the export share, which is about 0.3 for the Chinese economy.
} 
cratic elements are the residuals from a projection of the original variables on the common factors. As the common and idiosyncratic components are orthogonal, the further analysis can be conducted separately for them. In particular, the integration and cointegration properties of the common factors are examined by time series methods such as ADF tests and the Johansen (1995) reduced rank approach. Because the idiosyncratic components are independent by construction, their analysis can be based on standard panel tests such as those of Levin, Lin and Chu (2002) and Pedroni (1999, 2004). The cointegration vector for the common components is estimated using the Johansen (1995) reduced rank ML procedure. In case of the idiosyncratic components, efficient estimation techniques are available. See Pedroni (1999) for fully modified OLS and Mark, Ogaki and Sul (2005) for dynamic OLS methods. As they control for potential endogeneity of the regressors and serial correlation, asymptotically unbiased estimates of the long run can be obtained.

\section{$5 \quad$ Data and empirical results}

Annual data are available for 28 Chinese provinces and a sample period from 1992 to 2010. Sichuan and Chongqing are merged to a single area since both provinces formed a single administrative unit up to 1997 . Due to missing values in the price index of investment, Hainan is not considered. The price index for investment is also missing for most years in Guangdong. As this province is very important for Chinese exports, it has been included taken the national price index for investment as a proxy. Tibet is excluded because of a more general lack of data. The provinces are listed in Table 1, together with the geographical classification. 
-Table 1 about here-

Regional real GDP and real exports are available at the China Statistical Database until 2004, whereas values for subsequent years are from the Chinese Statistical Yearbook. Despite doubts about combining two sources of data, both are consistent to each other since they are managed by the National Bureau of Statistics of China. As Chinese data does not provide any information about the capital stock, it needs to be constructed. Capital build-up is obtained from annual gross capital formation reported in the China Statistical Database using a perpetual inventory technique following Zhang (2008) and $\mathrm{Wu}$ (2009). Nominal values are deflated by the price index for investment goods $(2010=1)$ to derive real investment. Average depreciation rates for individual provinces are taken from $\mathrm{Wu}$ (2009). Finally, the initial capital stock (1992) is determined by a growth rate approach, where growth is approximated by the average annual real GDP change over the 1990-95 period.

-Table 2 about here-

The variables are decomposed into common and idiosyncratic factors by principal component analysis. As the components could be nonstationary, the decomposition is based on the differenced data, as suggested by Bai and $\mathrm{Ng}$ (2004). Once the factors have been estimated, they are re-cumulated to match the stochastic properties of the original data. The idiosyncratic series stem from a projection of the variables on their common com- 
ponents. Inference on the unit root properties is obtained by the usual time series tests in case of common factors. As the defactored series are independent by construction, stochastic trends in the idiosyncratic components are explored by standard panel unit root tests. At this stage the test suggested by Levin, Lin and Chu (2002) is applied. Under the null hypothesis, the series under consideration shows a random walk behavior for all panel members.

-Table 2 about here-

The number of principal components is estimated through the BIC3 criterion; see Bai and $\mathrm{Ng}$ (2002). As the cross section and time series dimensions of the panel are approximately of the same magnitude, this measure tends to be superior over alternatives. The first two principal components are selected for each of the series involved. They reflect 75 percent of the overall variation of real income, 70 percent in case of exports and 81 percent for the capital stock. The common factors arise as a linear combination of the principal components per variable, where weighting factors reflect the contribution to the overall variance ${ }^{3}$. While the common factors are nonstationary, the unit root hypothesis can be rejected for the idiosyncratic components (Table 2). Therefore, if a long run relationship between regional GDP, exports and capital exists, it will emerge due to nationwide trends.

\footnotetext{
${ }^{3}$ The choice of two principal components per variable is somewhat arbitrary, as the information criterion does not converge in the application. However, the results can be replicated, if the factors are obtained from a different number of principal components. In fact, the additional contribution to the overall variance appears to be rather minor, if further components are extracted. Results are available from the authors upon request.
} 
In fact, there is strong evidence for a long run relationship between the common factors of GDP, exports and the capital stock (Table 3). The cointegration vector has been normalized to the coefficient of real GDP. The signs of the parameters are in line with theoretical reasoning; see the left column of Table 4.

An acceleration in exports or the capital stock is associated with a GDP increase. Furthermore, the impact of exports is positive, and the size of the coefficient (0.54) exceeds the Chinese export share in GDP (0.3). Thus, the export led growth hypothesis is supported. The feedback coefficients indicate that GDP adjusts in response to deviations from the long run, while capital is weakly exogenous. For exports, the results are less clear, as the error correction term is significant at the margin. This would be in contrast to export driven growth, as exports should be pre-determined. But the null hypothesis of weak exogeneity of both exports and the capital stock cannot be violated at the 0.05 level (Chi square statistic 4.693, $p$-value 0.096).

\section{Tables 3 and 4 about here-}

Although the export led growth hypothesis holds for the overall economy, the speed of adjustment to shocks in export markets might differ across regions. This can be conducted from the analysis of the feedback coefficients at the provincial level. According to the evidence on weak exogeneity, this exercise can be efficiently done in a conditional single equation model. Here, regional GDP growth is regressed on the contemporaneous and one-period lagged growth rates of exports and capital, its one period own lag and the lagged error correction term specified in Table 4. Non significant variables are 
then eliminated successively $(0.1$ level $)$. The feedback coefficients for the individual regions are listed in Table 5.

Apart of a few regions located in the Western part, the bulk of parameters are well signed and significant at conventional levels. Thus, the GDP reaction to export shocks is widespread and rather homogeneous across the country. Although export shares may vary across regions, provinces are interrelated, as firms from different areas are embedded in supplier chains for export production. Overall, the results indicate that the adjustment pattern is not limited to some provinces.

-Table 5 about here-

\section{Conclusions}

Using a production function approach, this paper examines to which extent regional GDP growth in China is export driven. In a panel of 28 Chinese provinces, series are splitted into common and idiosyncratic components, the latter being stationary. The findings indicate cointegration between the common components of GDP, the capital stock and exports. In the long run equilibrium, exports increase GDP by more than their impact expected from the national accounts. While exports and capital appear to be weakly exogenous, GDP responds to deviations from the long run. This adjustment pattern is rather homogeneous and widespread, except of some provinces located in the Western part of the country. 


\section{References}

Bai J, Ng S (2002): Determining the number of factors in approximate factor models, Econometrica 70, 191-221.

Bai J, Ng S (2004): A PANIC attack on unit roots and cointegration, Econometrica 72, $1127-1177$.

Bao S, Chang GH, Sachs JD, Woo WT (2002): Geographic factors and China's regional development under market reforms, 1978-1998, China Economic Review 13, 89-111.

Campbell J, Perron P (1991): Pitfalls and opportunities: What macroeconomists should know about unit roots, in Blanchard OJ, Fischer S (eds): NBER macroeconomic annual, 1991, MIT Press, Cambridge Massachusetts, 141-201.

Chen B (2011): Export variety, revenue and productivity in China, Review of International Economics 19, 341-355.

Dreger C, Herzer D (2012): A further examination of the export-led growth hypothesis, Empirical Economics, forthcoming.

Dreger C, Zhang Y (2011): The Chinese impact on output growth and inflation in the industrial countries, DIW Discussion Paper 1151.

Gengenbach C, Palm FC, Urbain, J-M (2006): Cointegration testing in panels with common factors, Oxford Bulletin of Economics and Statistics 68, Supplement, 683-719.

Grossman GM, Helpman E (1991) Innovation and growth in the global economy. MIT Press, Cambridge, Mass.

Helpman E, Krugman P (1985). Market structure and foreign trade. MIT Press, Cambridge, Mass. 
Johansen S (1995): Likelihood based inference in cointegrated vector autoregressive models, Oxford University Press, Oxford.

Kwan CC, Kwok B (1995): Exogeneity and the export-led growth hypothesis: The case of China, Southern Economic Journal 61, 1158-1166.

Levin A, Lin CF, Chu CSJ (2002): Unit root tests in panel data: Asymptotic and finitesample properties. Journal of Econometrics 108, 1-24.

Ljungwall C (2006): Export-led growth: Application to China's provinces, 1978-2001, Journal of Chinese Economic and Business Studies 4, 109-126.

Mark NC, Ogaki M, Sul D (2005): Dynamic seemingly unrelated cointegrating regressions, Review of Economic Studies 72, 797-820.

Pedroni P (1999): Critical values for cointegration tests in heterogeneous panels with multiple regressors, Oxford Bulletin of Economics and Statistics 61, 653-670.

Pedroni P (2004): Panel cointegration, asymptotic and finite sample properties of pooled time series tests with an application to the PPP hypothesis, Econometric Theory $20,597-625$.

Shan J, Sun F (1998): On the export led growth hypothesis: The econometric evidence from China, Applied Economics 30, 1055-1065.

Wu Y (2009): China's Capital Stock Series by Region and Sector, University of Western Australia, Discussion Paper 09.02.

Zhang J (2008): Estimation of China's provincial capital stock (1952-2004) with applications, Journal of Chinese Economic and Business Studies 6, 177-196. 
Figure 1: Export and GDP growth in the Chinese economy

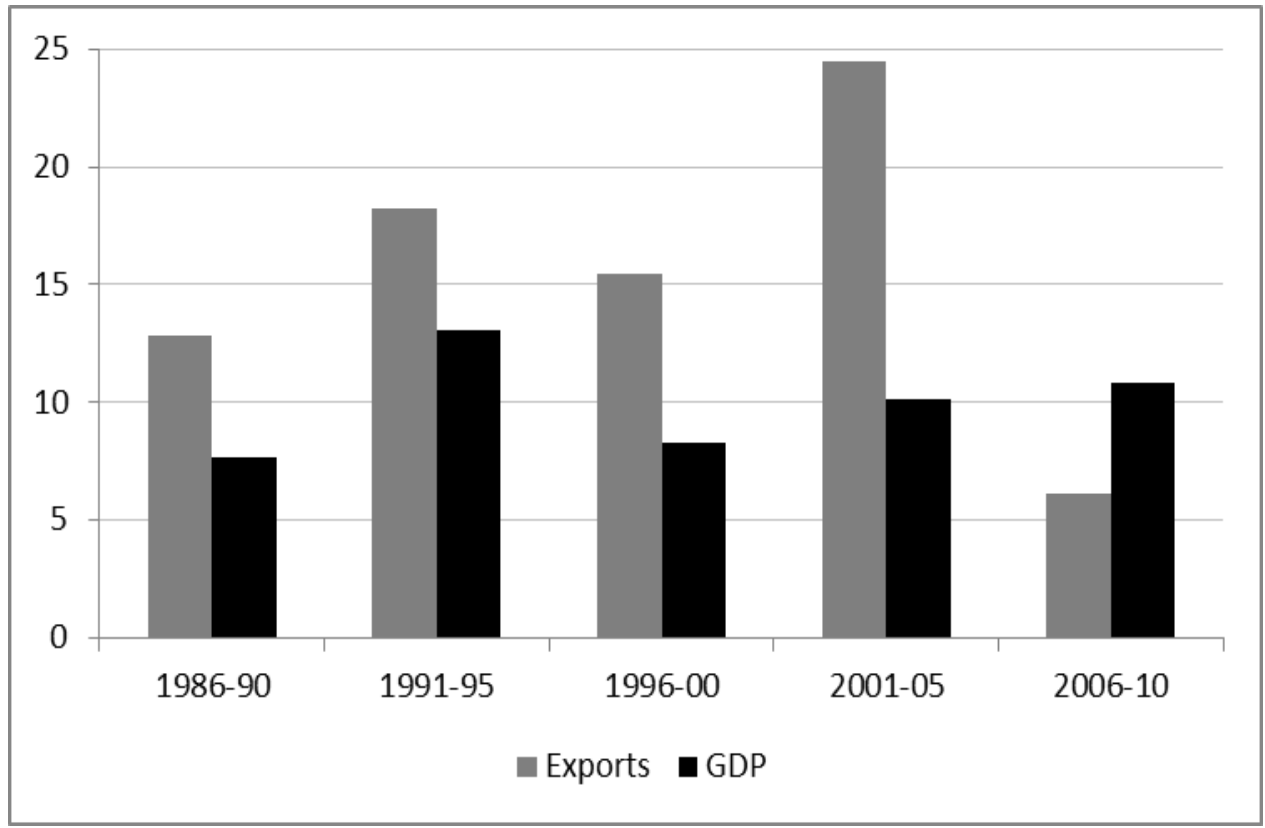

Figure 2: Export and private consumption share in GDP

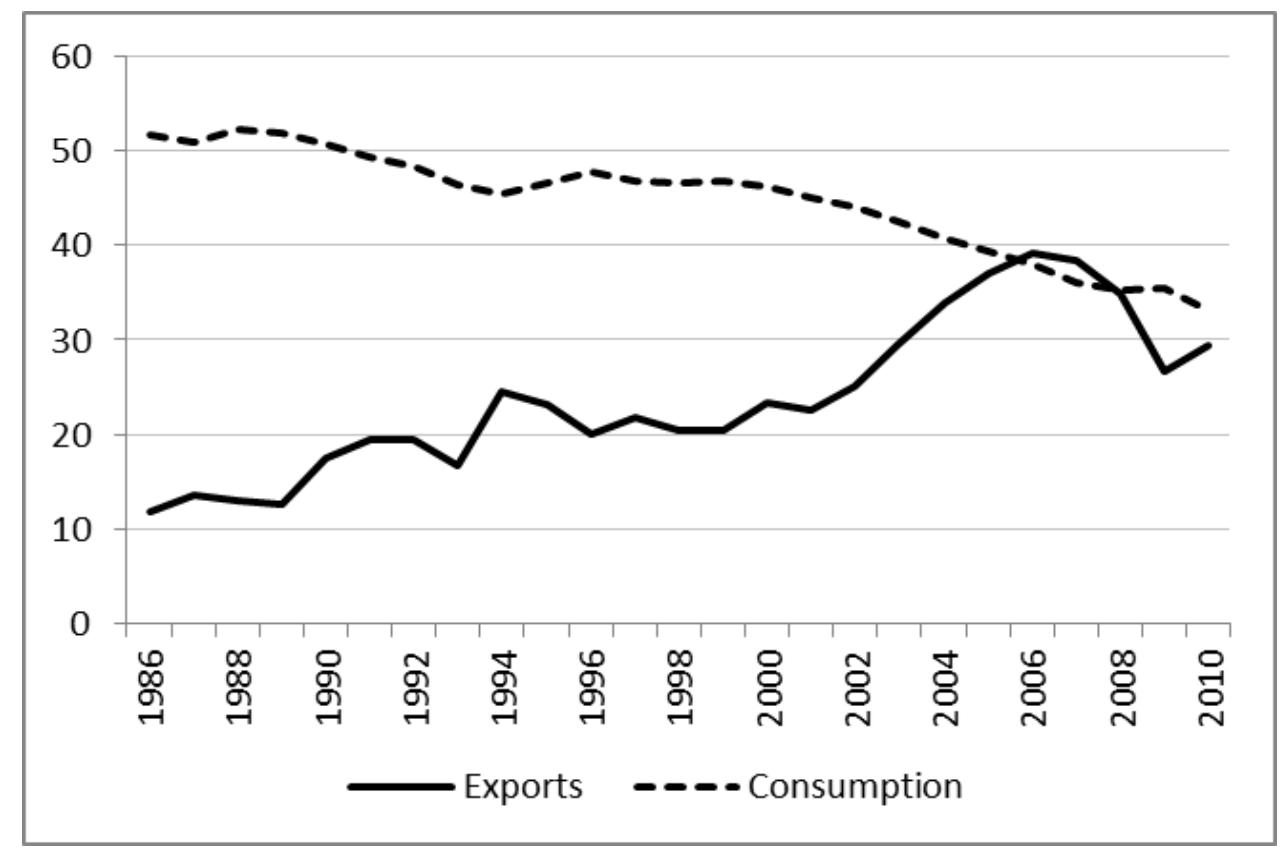

Source: IMF World economic outlook. 
Table 1: Chinese provinces in the analysis

\begin{tabular}{|l|l|}
\hline Western regions & $\begin{array}{l}\text { Gansu, Guizhou, Ningxia, Qinghai, Shaanxi, Sichuan, } \\
\text { Xinjiang, Yunnan }\end{array}$ \\
\hline Central regions & $\begin{array}{l}\text { Anhui, Heilongjiang, Henan, Hubei, Hunan, Inner } \\
\text { Mongolia, Jiangxi, Jilin, Shanxi }\end{array}$ \\
\hline Coastal regions & $\begin{array}{l}\text { Beijing, Fuijan, Guangdong, Guangxi, Hebei, Jiang- } \\
\text { su, Liaoning, Shandong, Shanghai, Tianjin, Zhejiang }\end{array}$ \\
\hline
\end{tabular}

Note: Geograhical classification according to Bao, Chang, Sachs and Woo (2002). 
Table 2: Unit root analysis

\begin{tabular}{|l|c|c|}
\hline & Common component & Idiosyncratic component \\
\hline GDP & -3.494 & $-5.030^{*}$ \\
Exports & -2.486 & $-6.647^{*}$ \\
Capital stock & 0.575 & $-9.237^{*}$ \\
\hline
\end{tabular}

Note: Sample period 1992-2010, 28 provinces. Variables in constant prices. The optimal lag length in the regressions is determined by the general-to-simple approach suggested by Campbell and Perron (1991). Unit roots are examined via the ADF regression (with a constant and a linear time trend) in case of the common component, and via the Levin, Lin and Chu (2002) test for the idiosyncratic component. An asterisk denotes the rejection of the unit root hypothesis at least at the 0.05 level. 
Table 3: Cointegration rank of common components model

\begin{tabular}{|c|c|c|}
\hline$r \leq 0$ & $r \leq 1$ & $r \leq 2$ \\
\hline $35.35^{*}$ & 11.91 & 0.19 \\
\hline
\end{tabular}

Note: Sample period 1992-2010. Johansen (1995) trace statistic for the null hypothesis that the cointegration rank does not exceed a prespecified number. Lag length of VAR determined by Schwarz criterion, equal to 2 for VAR level model. To correct for finite sample bias, the trace statistic is multiplied by the scale factor $(T-p k) / T$, where $T$ is the number of the observations, $p$ the number of the variables and $k$ the lag order of the underlying VAR (Reimers, 1992). Critical values from MacKinnon, Haug and Michelis (1999), also valid for the finite sample correction. A * indicates the rejection of the null hypothesis of no cointegration at least on the 0.05 level of significance. 
Table 4: Cointegration vector and feedback mechanisms

\begin{tabular}{|l|c|c|}
\hline & Cointegration vector & Feedback vector \\
\hline GDP & 1 & $-0.560(0.107)$ \\
\hline Exports & $-0.544(0.095)$ & $1.680(0.864)$ \\
\hline Capital stock & $-0.851(0.394)$ & $-0.002(0.023)$ \\
\hline
\end{tabular}

Note: Sample period 1992-2010. Reduced rank ML estimation of the cointegration and feedback vector according to Johansen (1995). Standard errors in parantheses. 
Table 5: Feedback coefficients at regional level

\begin{tabular}{|c|c|c|c|}
\hline Coastal regions & & Hubei & $-0.036(0.012)$ \\
\hline Beijing & $-0.034(0.012)$ & Hunan & $-0.037(0.013)$ \\
\hline Fujian & $-0.028(0.014)$ & Inner Mongolia & $-0.068(0.015)$ \\
\hline Guangdong & $-0.067(0.016)$ & Jiangxi & $-0.054(0.016)$ \\
\hline Guangxi & $-0.066(0.017)$ & Jilin & $-0.056(0.015)$ \\
\hline Hebei & $-0.032(0.018)$ & Shanxi & $-0.044(0.018)$ \\
\hline Jiangsu & $-0.070(0.015)$ & Western regions & \\
\hline Liaoning & $-0.036(0.019)$ & Gansu & $-0.032(0.024)$ \\
\hline Shandong & $-0.058(0.015)$ & Guizhou & $-0.035(0.011)$ \\
\hline Shanghai & $-0.025(0.013)$ & Ningxia & $-0.014(0.016)$ \\
\hline Tianjin & $-0.057(0.022)$ & Qinghai & $-0.037(0.022)$ \\
\hline Zhejiang & $-0.060(0.018)$ & Shaanxi & $-0.033(0.015)$ \\
\hline Central regions & & Sichuan & $-0.056(0.015)$ \\
\hline Anhui & $-0.040(0.024)$ & Xinjiang & $-0.092(0.020)$ \\
\hline Heilongjiang & $-0.056(0.021)$ & Yunnan & $-0.034(0.020)$ \\
\hline Henan & $-0.041(0.018)$ & & \\
\hline
\end{tabular}

Note: Sample period 1992-2010. Feedback parameters in regional error correction models with a common error correction term. Standard errors in parantheses. 